\title{
“Die Weltgeschichte ist das Weltgericht”
}

\section{Citation}

Rosen, Michael. 2014. "Die Weltgeschichte ist das Weltgericht." In Internationales Jahrbuch des deutschen Idealismus, ed. F. Rush: 256-72. Berlin: De Gruyter.

\section{Published Version}

doi:10.1515/9783110378818.256

\section{Permanent link}

http://nrs.harvard.edu/urn-3:HUL.InstRepos:32186260

\section{Terms of Use}

This article was downloaded from Harvard University's DASH repository, and is made available under the terms and conditions applicable to Open Access Policy Articles, as set forth at http:// nrs.harvard.edu/urn-3:HUL.InstRepos:dash.current.terms-of-use\#OAP

\section{Share Your Story}

The Harvard community has made this article openly available.

Please share how this access benefits you. Submit a story.

\section{Accessibility}




\section{"Die Weltgeschichte ist das Weltgericht"}

"Die Weltgeschichte ist das Weltgericht" - "The history of the world is the Last Judgement” - is one of the most famous aphorisms in Hegel's works. It also, on its most obvious interpretation, seems to support a deeply unsympathetic image of his philosophy of history. If the Last Judgement is not something that is carried out by an omniscient, omnipotent and (above all) just creator-god but left to the verdict of history then it looks as if Hegel is (as Benjamin called him) a Gewaltmensch and a mystic of violence, ${ }^{1}$ someone who is inspired by the idea that the World Spirit fights on the side of the big battalions. In this paper, I shall explore the background to this aphorism. In brief, I argue that the German Idealists do indeed find ideals in secular history that correspond to what had previously been the prerogative of a transcendent deity but that this relationship is a far more complex one than a simple transfer to the outcome of history of God's erstwhile role as the distributor of deserved rewards and punishments.

\section{I}

To present this transition from God to history I shall focus on Kant. The interpretation that I shall advance sets itself strongly against a received image of Kant's enterprise in relation to religion which goes back (at least) to Heinrich Heine. According to Heine (in his History of Religion and Philosophy in Germany) Kant was the German Robespierre. With his "guillotine of ideas" and the restriction of human knowledge to the bounds of

\footnotetext{
1 “Ich glaubewir würden, wenn wir uns seine Sachen auf kurze Zeit vornehmen würden bald auf die geistige Physiognomie kommen die daraus blickt: die eines intellektuellen Gewaltmenschen, eines Mystikers der Gewalt, die schlechteste Sorte die es gibt: aber auch Mystiker.“ Walter Benjamin to Gerhard Scholem, 31 January 1918, in Briefe I (Frankfurt a.M.: Suhrkamp, 1978), p.171
} 
sense, said Heine, Kant was not just a regicide but a deicide - he put an end to God! Now indeed, Heine admitted, Kant, in his practical philosophy, had allowed God back in as a “postulate”, but we shouldn’t treat this too seriously. Kant's old servant, Lampe, was pious and Lampe must have his God. The true motto of the Critical Philosophy was: abandon hope!

Heine’s excellent jokes notwithstanding, his image of Kant is grossly one-sided. Yes, it is true that Kant is fiercely destructive of the pretensions of rationalist metaphysics to give us speculative knowledge of God's nature. But was not his own statement of his project in the Critique of Pure Reason "to limit knowledge to make room for faith"? If all that we can know is what can be given to us through our senses, that does not mean (unless you think of Kant as a kind of verificationist - which he was certainly not) that that is all that we can intelligibly think, believe or hope for. Can Kant plausibly regard himself as the friend of religion, rather than its enemy? This is certainly how he presents the Critique of Pure Reason:

On a cursory view of the present work it may seem that its results are merely negative, warning us that we must never venture with speculative reason beyond the limits of experience. Such is in fact its primary use. But such teaching at once acquires a positive value when we recognize that the principles with which speculative reason ventures out beyond its proper limits do not in effect extend the employment of reason, but, as we find on closer scrutiny, inevitably narrow it. These principles properly belong to sensibility, and when thus employed they threaten to make the bounds of sensibility coextensive with the real, and so to supplant reason in its pure (practical) employment. ${ }^{2}$

While we cannot claim rational warrant for religious beliefs, Kantianism preserves divine transcendence from rationalist critique by insulating it from the secular realm.

On the other hand, the defence of religion this gives is severely limited. Although religion is preserved from attack, it is, at the same time, restricted to a domain that is

\footnotetext{
${ }^{2}$ Critique of Pure Reason, Bxxiv
} 
private and non-rational. It is one thing to say that religious belief is not unintelligible, self-contradictory or open to empirical refutation; it is another to say that we have any good reason (rather than merely a strong emotional impulse) to hold it. As Allen Wood remarks sharply but, surely, not without some justification, of the related doctrine of noumenal freedom: while there may be no contradiction in believing in it, nor is there any contradiction in belief in fairies, witches and Prince Charming. ${ }^{3}$ The picture changes considerably, however, when we look at Kant's philosophical approach to religion from the side of his moral philosophy. Seen from that angle, Kant's conception of religion emerges, I shall argue, as "Socratic" in two quite different senses that I shall explain below.

One way in which Kant's position is "Socratic" is in relation to what is, arguably, the oldest and deepest problem in moral philosophy: the Euthyphro dilemma. As we find the dilemma in its original form in Plato's dialogue, Euthyphro, it is simply the following question: "Is the pious loved by the gods because it is pious, or is it pious because it is loved by the gods?” (10a) The question broadens naturally, however, into a general question about morality and applies with particular force in a world in which there is a single God (not “gods”). It becomes: is morality binding on God or is God's omnipotence such that goodness itself is a product of his sovereign, commanding will? Where does Kant stand?

Frederick Beiser in his characteristically erudite and unfailingly interesting treatment of German political and social thought at the end of the eighteenth century, makes a bold assertion about Kant's views:

\footnotetext{
${ }^{3}$ Allen Wood, Kantian Ethics (Cambridge: Cambridge U.P., 2008) 137
} 
The novelty of Kant's new ethics becomes clear in its broader historical context. Although Kant was not fully aware of it, his Rousseauian ideas mark a profound break with the prevalent natural law tradition of Pufendorf and the Wolffian school. This tradition places the source of moral value not in the human will but in the providential order. The law of nature is the end appropriate to a thing, the purpose God intended for it. To know our moral obligations, then, we need to know "the vocation of man", our place in the Creation or role in the divine design. Although Pufendorf and Wolff maintained that natural law can be justified by natural reason alone, they never ceased to regard God as its creator and enforcer. Compared to this tradition, Kant's new ethics are revolutionary. The source of moral value is the rational will inside us, not the providential order outside us. Here lies the real depth and impact of Kant's Copernican revolution. This took place not only in epistemology but also in ethics. Just as the natural world depends on the laws of the understanding, so the moral world depends on the laws of the will. Both ethics and epistemology have become anthropocentric.

The political implications of Kant's new ethics are ... radical in the extreme. If the human will creates moral values, so that it is obliged to obey only the laws of its own making, then it has the right to recreate the entire social and political world. ${ }^{4}$

For present purposes, the most important part of this passage is towards the very end: it is the claim that, for Kant, "the human will creates moral values". Is this so? If it is, then Kant will stand on the anti-Platonic side of the Euthyphro dilemma: moral value will be the product of a will - not, in this case, the will of God (or of "the gods") but of human beings themselves. It would, of course, be foolish to deny that Kant believes that the moral will is "a law to itself" (Ak. 4:440). But does that mean that the human will “creates” moral values, as Beiser asserts? I do not believe so.

Kant's most extensive discussion this issue so far as I know comes in the Lectures on Ethics. I shall quote the passage in full:

Can we, even without presupposing God's existence and His arbitrium, derive all obligations from within? Responsio: not merely in the affirmative, for this, rather, is ex natura rei, and we conclude from this to God's choice.

From the arbitrium divinum I cannot myself obtain the relevant concepts of the good, unless the concept of the morally good be assumed beforehand; apart from that, the sheer arbitrium of God is god merely in a physical sense. In short, the judgement as to the perfection of God's arbitrium presupposes the investigation of moral perfection.

\footnotetext{
${ }^{4}$ Enlightenment, Revolution and Romanticism (Cambridge, MA: Harvard U.P., 1992), pp. 30-31
} 
Supposing the arbitrium of God to be known to me, where is the necessity that I should do it, if I have not already derived the obligation from the nature of the case: God wills it - why should I? He will punish me; in that case it is injurious, but not in itself wicked; that is how we obey a despot; in that case the act is no sin, in the strict sense, but politically imprudent; and why does God will it? Why does He punish it? Because I am obligated to do it, not because He has the power to punish. The very application of the arbitrium divinum to the factum, as a ground, presupposes the concept of obligation; and since this constitutes natural religion, the latter is a part, but not the basic principle, of morality. It is probable that, since God by His arbitrium, is the ground of all things, this is also the case here; He is indeed the ground of it, but not per arbitrium, for since He is the ground of possibility, He is also the material ground (since in Him all things are given) of geometrical truths and morality. In him there is already morality, therefore, and so His choice is not the ground.

The quarrel between reformers and Lutherans over arbitrium divinum and decretus absolutus is based on the fact that even in God morality must exist; and every conception of the divine arbitrium itself vanishes, if morality is not presupposed; this cannot, however, be demonstrated from the world (where it is merely possible), since the good things of the world may merely be physical consequences. How dreadful, though, is a God without morality. (Ak. 27:9-10)

I think that this passage shows two things: first, that Kant is passionately exercised by the Euthyphro dilemma, and, second, that he comes down firmly on Plato’s side. Morality, as Kant describes it here, exists "even in God". For God, morality is not a constraint, imposed externally, but corresponds to his inner essence. The priority and independence of human morality is presented epistemically: we can know morality without recourse to God. Yet this certainly does not mean, as Beiser puts it, that morality is a human creation, a quite different claim.

Yet what weight should we give to the passage I have just cited? Striking as it is, it comes from lectures given by Kant, not a publication. Moreover, those lectures were given between 1762 and 1764, and the note-taker was none other than Johann Gottfried Herder - not, you might think, the most impartial spectator of Kant's thought. Perhaps this was just Kant while he was still slumbering in the enchanted castle of dogmatism. If that is what you think, however, I have another passage for you: 
It was the moral ideas that gave rise to that concept of a Divine Being which we now hold to be correct ... it is these very laws that have led us, in virtue of their inner practical necessity, to the postulate of a self-sufficient cause, or of a wise Ruler of the world, in order that through such agency effect may be given to them. We may not, therefore, in reversal of such a procedure, regard them as accidental and derived from the mere will of the Ruler, especially as we have no conception of such a will, except as formed in accordance with these laws. So far, then, as practical reason has the right to serve as our guide, we shall not look upon actions as obligatory because they are the commands of God, but shall regard them as divine commands because we have an inward obligation to them. (Critique of Pure Reason, A818-19, B846-47)

It seems to me that this passage reveals precisely the same position. Morality is not to be seen as a product of God's will because of his power of command; it is as valid for God as it is for human beings. And this passage comes, not from some possibly dubious lecture notes from Kant's early years, but from the central text of the whole corpus of the “Critical Philosophy”: the Critique of Pure Reason, as published in 1781 and revised in 1787. Pace Beiser, morality, on the view embraced by Kant, has its source neither in the will of God nor the will of man, although it is internal to and constitutive of each, for the simple reason that it does not, in that sense, have a "source" at all.

\section{II}

Because he takes the Platonic side in responding to the Euthyphro dilemma I label Kant's view of religion "Socratic" in a first sense. The second sense in which I describe it as "Socratic" is very different: it derives from Nietzsche's use of the term in The Birth of Tragedy. As is well-known, Nietzsche there describes Greek tragedy as embodying a fusion of two impetuses, which he labels “Apollonian” and "Dionysian”. His starting point is that all human cultures face the standing problem of coming to terms with the unvarying facts of death and suffering. Apollonianism and Dionysianism are two 
strategies for dealing with suffering. They are epitomized (as Nietzsche describes them) in dreams and intoxication respectively. The Dionysiac finds ways - through drugs, dance, ritual, the frenzy of battle or whatever else - so to transform his or her psyche as to become impervious or indifferent to suffering. Apollonians console themselves by contemplating a realm of order, beauty and happiness beyond our own - the prototypical aesthetic attitude. The Greek gods, originally at least, were Apollonian; not so much wise and just governors of the human world as the beautiful denizens of a higher realm:

The same impulse which calls art into being as the contemplation and consummation of existence, seducing one to a continuation of life, was also the cause of the Olympian world which the Hellenic "will" made use of as a transfiguring mirror. Thus do the gods justify the life of man: they themselves live it - the only satisfactory theodicy! ${ }^{5}$

Less often noticed however, but more important for my purposes here, is the impetus that, according to Nietzsche, displaced the culture of tragedy: what he calls "Socratism". The "Socratic" response to suffering that follows Dionysianism and Apollonianism is quite different, however. Rather than escaping from suffering through ecstatic selftransformation or the aesthetic contemplation of another realm, Socratism attempts to integrate the acceptance of suffering as part of its wider project of making the world intelligible - to give suffering a "meaning" in a narrower and more direct sense. It was with Socrates, says Nietzsche, that a "profound illusion ... first saw the light of the world":

... the unshakable faith that thought, using the thread of causality, can penetrate the deepest abysses of being, and that thought is capable not only of knowing being but even of correcting it. This sublime metaphysical illusion accompanies science as an instinct and leads science again and again to its limits at which it must turn into art - which is really the aim of this mechanism. ${ }^{6}$

\footnotetext{
${ }^{5}$ Birth of Tragedy, Sect. 3

${ }^{6}$ Birth of Tragedy, Sect. 15
} 
Socratism does not have to be overtly religious, but, even without a creator-god or the belief in personal immortality, it plays an equivalent role in satisfying the human need for reconciliation and consolation. In its recognizably religious form, however, it leads naturally to the omnipotent, omniscient, omnibenevolent God of monotheism, and, hence, to the problem of theodicy.

Although the term "theodicy" is a (relatively) modern one, the idea that the existence of evil requires a rational response on the part of the religious believer goes back at least as far as the Book of Genesis. Indeed, Hans Blumenberg goes so far as to assert that the whole history of Western culture is a series of attempts to resolve the problem of theodicy that is haunted, as he puts it, by the "threat of Gnosticism" - that a basically monotheistic religious framework, when it addresses the problem of evil, is constantly pulled towards a dualism that makes evil into an independent principle at odds with the intrinsic nature of the deity. The basic moves by which the Western tradition has responded to the "problem of evil" are relatively easy to summarize. The dominant answer, of course, stretching from the Book of Genesis, through St Augustine and including the founders of Protestantism, Luther and Calvin, has been the story of the Fall - the idea that death and suffering are just punishments for Original Sin. But whose sin? Adam's? But why then should we now be punished for the sinful actions of someone who is simply our (very remote) ancestor?

In the $17^{\text {th }}$ and $18^{\text {th }}$ centuries that story came to be challenged (though never completely replaced) by another, technically speaking, optimistic view: the idea that we live in a world that should be seen as a realization of God's benevolence, a world within which (to put it in Locke's language) each is to be preserved as much as may be. Where 
the story of Original Sin leads us to doubt God's benevolence (if he is benevolent, why does he punish us apparently unjustly?) optimism, obviously, casts doubt on his omnipotence - is this really as good as it gets? This, of course, is why it is often said that theodicy came to an end with the Lisbon Earthquake (1755).

If religion, for Kant, were really no more than a set of non-rational beliefs about the non-empirical realm, as one might think if one looked at things solely from the perspective of his theoretical philosophy, then it might seem that the problem of theodicy would not arise; suffering and evil are, after all, aspects of the empirical world. Yet Kant did indeed address the issue in an essay published in 1791 called: "On the Failure of All Philosophical Attempts at Theodicy”. He divides the objections to the deity through the existence of evil into three. The first two correspond to the existence of human evil (there are evil agents) and apparently natural evil (suffering). But it is the fact that Kant identifies a third kind of "counterpurposiveness" that is of great significance. Kant calls this "the counterpurposiveness of justice". It is, he asserts, the most important reason that we have to doubt God's goodness. He writes:

It is remarkable that of all the difficulties in reconciling the course of world events with the divinity of their creator, none imposes itself on the mind as starkly as that of the semblance in them of a lack of justice. If it comes about (although it seldom happens) that an unjust, especially violent, villain does not escape unpunished from the world, then the impartial spectator rejoices, now reconciled with heaven. No purposiveness of nature will so excite him in admiration of it and, as it were, make him detect God's hand in it. Why? Because nature is here moral, solely of the kind we seldom can hope to perceive in the world. ${ }^{7}$

What does Kant mean by "justice"? In this context it is simple and straightforward enough: it is the "disproportion between the impunity of the depraved and their crimes” (Ak. 8:257) that leads us to doubt divine benevolence. It is not just that bad

\footnotetext{
${ }^{7}$ Ak. 8:260
} 
things happen to good people but, as Kant seems to feel even more intensely, that bad things fail to happen to bad ones.

Notoriously, according to Kant (although many of his admirers find it unpleasant to have to concede the fact) actions, to have moral worth, must be performed for the sake of duty and for that reason alone. Here is one of the many passages in which he states this quite plainly:

... that the human being ought to perform his duty quite unselfishly and that he must altogether separate his craving for happiness from the concept of duty, in order to have this concept quite pure: of that he is aware with the utmost clarity, or, should he believe that he is not, it can be required of him that he be so, as far as he can; for the true worth of morality is to be found in this purity, and he must therefore also be capable of it. (Ak. 8:284)

Yet happiness is not absent from Kant's account of morality. Moral theory [die Moral], he writes in the Critique of Practical Reason, "is not properly the doctrine of how we are to make ourselves happy but of how we are to become worthy of happiness" (Critique of Practical Reason, Ak. 5:130). The “highest good”, according to Kant, requires that happiness be combined "in the most exact proportion" with the worthiness that comes from moral conduct. (Ak. 5:129-30) It is this, he says there, that connects morality with religion. Only when religion is added to morality "does there also enter the hope of some day participating in happiness to the extent that we have been intent upon not being unworthy of it”. (Ak. 5:130)

This position is certainly bizarre. On the one hand, it is maintained, we must not act for the sake of happiness, at the price of depriving our actions of all moral worth. On the other hand, we may (indeed, to follow Kant, must) hope that, if our actions do in fact have moral merit, happiness will ensue. So I am to hope for happiness from actions that are, not - indeed, if they are to make me worthy of happiness, cannot be - aimed at 
happiness. We may well wonder what led Kant to take such a convoluted (if not, strictly speaking, contradictory) position. In what follows I shall offer an explanation.

Injustice, as Kant sees it, can be of two kinds: either good people can fail to receive an appropriate measure of happiness or bad ones fail to receive the punishment they deserve. Kant distinguishes between the two cases and is more concerned with the second one, where the bad go unpunished. For most contemporary philosophers punishment is not something intrinsically good. Even those few who believe in "desert" don't think that it is actually good that bad things should happen to bad people so much as that, if bad things have to happen at all, then it is better (or, at least, less bad) that they should happen to bad people rather than to good ones. Such is the hold that a general "welfarism" has on modern thought, that we find it hard to find any sympathy for the idea that it is can be better to diminish overall well-being, even when there are no good consequences whatsoever.

Kant's position is far more radical. It is the intrinsic injustice that bad things should fail to happen to bad people that chiefly commands his attention. How so? Kant argues that the absence of punishment for the wicked is a more significant barrier to believing in the goodness of the world than the absence of reward for the virtuous. Believing that God is benevolent, we must presume that he has so arranged things in this world as to further our happiness, he says. This creates, if you will, an expectation of happiness on our part yet it does not create an entitlement to it. At the same time, we are also subject to the requirements of morality. In fulfilling these requirements we keep God's law, but we do not thereby create a claim on God's benevolence. So, Kant claims, 
there is an asymmetry between the absence of happiness for the good and the happiness of the wicked:

... the lament over the lack of justice shown in the wrongs which are the lot of human beings here on earth is directed not at the well-being that does not befall the good, but at the ill that does not befall the evil (although if well-being occurs to the evil then the contrast makes the offence all the greater). For under divine rule even the best of human beings cannot found his wish to fare well on God's beneficence, for one who only does what he owes can have no rightful claim on God's benevolence. (Ak. 8:258)

In other words, while it would be good for God to reward the good, it is wrong that the bad go unpunished. This punishment is not, let us note, something that bad people owe as compensation to another individual - someone whom they have wronged, perhaps - or even to the whole community. It is, as Kant makes very clear, something that we should think of as good in itself:

... punishment in the exercise of justice is founded in the legislating wisdom in no way as mere means but as an end: trespass is associated with ills not that some other good may result from it, but because this connection is good in itself, i.e. morally and necessarily good. (Ak. 8:257)

When it comes to punishment, Kant is the purest of pure retributivists. What leads us to religion is not the thought that, since we have acted without consideration for our own happiness we deserve to be rewarded with happiness by a just God. Rather, it is the thought that there is something intolerable about a world in which the wicked go unpunished. As Kant remarks in a footnote at the end of the Metaphysics of Morals, "it is from the necessity of punishment that the inference to a future life is drawn”. (Ak. 6:490)

Kant's vision of justice in a future world, with its emphasis on the primacy of punishment, was itself hardly a cheerful prospect, however. If we look at the end of the Metaphysics of Morals, it is evident that Kant himself is profoundly disturbed by the consequences of his own argument. Having explained and endorsed the idea that the 
ancients too gave primacy to retribution and saw justice (like fate) as "[pronouncing] on right in accordance with an iron, inevitable necessity which we cannot penetrate further”, above even the power of Jupiter, (Ak. 6:489) Kant acknowledges that such an unyielding understanding of justice is hard to reconcile with the principle that God should be both just and loving:

For in view of the eventual multitude of criminals who keep the register of their guilt running on and on, punitive justice would make the end of creation consist not in the creator's love (as one must yet think it to be) but rather in the strict observance of His right (it would make God's right itself, located in His glory, the end). But since the latter (justice) is only the condition limiting the former (benevolence), this seems to contradict principles of practical reason, by which the creation of a world must have been omitted if it would have produced a result so contrary to the intention of its author, which can only have love for its basis.

From all this it is clear that in ethics, as pure practical philosophy of internal lawgiving, only the moral relations of men to men are conceivable by us. The question of what sort of moral relation holds between God and man goes completely beyond the bounds of ethics and is altogether inconceivable for us. This, then, confirms what was maintained above: that ethics cannot extend beyond the limits of men's duties to one another. (Ak. 6: 490-91)

And with this Kant closes the book! The austere slogan of retributivism was always: let justice be done although the world perishes (fiat justitia, pereat mundus). Kant's position seems even harsher - let justice be done even if we have to create a hell for it to be done in.

\section{III}

It is important to distinguish here between the desire for our own well-being as a motive for belief in an after-life and the idea that a world in which evil goes unpunished lacks the intelligible goodness that a "Socratic" form of religion requires. The concern for justice that leads us to believe in a future life does not have to be essentially "first personal" - it is not the virtuous agent claiming a reward in happiness for actions that have been 
performed not for the sake of happiness - but embodies a kind of third-personal vision. Nietzsche, if you recall, described the world of the Greek gods as offering an “Apollonian” form of reconciliation. If you follow Nietzsche, for the Greeks belief in the world of the gods meant that there existed a realm of perfect happiness. In contemplating this beautiful and happy realm, the ancient Greek, he imagined, was consoled, even without the promise that he himself might be part of it. If I am right, we can see a very similar thought at work in Kant: there exists a world of justice, even if that justice is "not for us". In this way, "Socratism" (the belief that the world contains an intelligible underlying structure) and "Apollonianism" (a vision of a to-us-as-individualsinaccessible realm of goodness) come together.

Although we cannot have speculative knowledge of God's intrinsic nature, nevertheless, for Kant, human beings are connected with the divine by morality and practical reason. The need for God to be (morally) intelligible underlies the essential coincidence between the "self-given law" of human freedom and the Divine Will. As he writes in the Metaphysics of Morals:

A law that binds us a priori and unconditionally by our own reason can also be expressed as proceeding from the will of a supreme lawgiver, that is, one who has only rights and no duties (hence from the divine will); but this signifies only the Idea of a moral being whose will is a law for everyone, without his being thought as the author [Urheber] of the law. (Ak. 6:227)

So morality extends from us to God and enables us to know something essential - indeed, what is most fundamental - about God's nature because the moral law applies to God too. God is not bound, limited or subject to morality - any of these metaphors would presuppose an opposition between God's will and something outside or superior to it but morality is essential to Him and reliably knowable by us. Morality, as Kant sees it, is 
"in us", certainly, but morality is not binding on us because it is something that we ourselves either create or "construct”. Kant would endorse Seneca's famous epigram: "I do not obey God, I agree with him”. We need to postulate a transcendent God not in order to have a source for morality - on the contrary, it is our independent knowledge of morality that leads us to God - but to deal with the fact of injustice: the discrepancy that exists between morality (desert) and happiness.

For Kant then, the idea of justice points us towards God and a world beyond. But not just to the world beyond. For justice, defined as it is by Kant as the appropriate proportion between well-being and moral worth, does not wholly transcend human capacities. It is true that, since moral worth requires that we act for the sake of duty alone, and since our moral self-knowledge can never confirm such purity of motivation, we can never establish the existence of true moral goodness in ourselves (let alone in others). But the requirements of morality are clear to us (or so Kant believes) and their transgression is plain. Moreover, human beings have the capacity to confront wrongdoers and punish them. So, while perfect justice may be unattainable, the pursuit of justice - the attempt to allocate pleasure and pain in accordance with desert - is indeed a viable human project. Justice is not just something that must wait for God's intervention or a future life: it is something that human beings can work towards in this world. Indeed, it is what gives history its point and purpose. A particularly clear (and, indeed, stirring) statement of this idea is to be found in the Lectures on Ethics (Collins Transcript of 1784-85):

The final destiny of the human race is moral perfection, so far as it is accomplished through freedom, whereby man, in that case, is capable of the greatest human happiness. God might already have made men perfect in this fashion, and allotted to each his share of happiness, but in that case it would not have sprung from the inner principium of the world. But that inner principle is freedom. The destiny of man is therefore to gain his greatest perfection by means 
of his freedom. God does not simply will that we should be happy, but rather that we should make ourselves happy, and that is the true morality. The universal end of mankind is the highest moral perfection; if only everyone were so to behave that their conduct would coincide with the universal end, the highest perfection would be thereby attained. Every individual must endeavour to order his conduct in accordance with this end, whereby he makes his contribution such that, if everyone does likewise, perfection is attained. (Ak. 27:470)

This is a very revealing passage indeed. Divine benevolence, in Kant's view, consists in God ordaining a world of justice - that is, the co-operation of happiness and freedom rather than in happiness alone. Justice is not to be understood as being out of reach because of human beings' mortality and physical frailty. On the contrary, the "highest human happiness" is attainable. But to achieve it is a collective endeavour that requires human beings to work together. It is not enough for one or a few of us to do our duty; every individual must make his contribution - the free riders must pay their fares or get off the bus! Yet, however remote the achievement of justice may be, it remains a viable political ideal.

Kant's conception of the highest good brings religion and politics together in the idea of an ethical community:

... this highest moral good will not be brought about solely through the striving of one individual person for his own moral perfection but requires rather a union of such persons into a whole ... toward a system of well-disposed human beings ... a universal republic based on the laws of virtue ... (Religion within the Limits of Reason Alone, Ak. 6:97-98)

Although the attainment of such a republic of virtue is, in principle, within human powers, it requires universal co-operation. For this reason, the duty of working towards it "will need the presupposition of another idea, namely, of a higher moral being through whose universal organization the forces of single individuals, insufficient on their own, are united for a common effect.” (Ak. 6:98) In other words, if human beings are to come 
together sufficiently to achieve justice as an ideal, we must also think of God as working with us in history. What we have, then, are the outlines of a possible vision of history as moving towards justice as human beings come to act virtuously together, not the ugly and reprehensible idea that I canvassed at the beginning of this lecture that whatever happens in history is just.

Kant's concern with justice as the "highest good" - that virtue should be rewarded and (most especially) wickedness punished in proportion to desert - thus leads in two directions: towards a belief in the Last Judgement and an after-life but also towards the "foundation of a kingdom of God on earth", a "universal republic based on the laws of virtue” as a goal of history. (Ak. 6:98) In contrast with the redemptive hopes of traditional religious faith (the opening of graves, lions lying down with lambs and so on) the realization of justice, we should note, is a project that is not incompatible with the facts of nature and science, however remote such a world may be from society as it is at present; justice can, in principle, be realized in this world without the need for miraculous divine intervention. It can be a matter of "general”, not "particular”, providence.

Moreover, the realization of justice can be a matter of hope, I claimed, even if we do not conceive of ourselves as its direct beneficiaries. Not every consoling vision has to be one whose realization we ourselves experience - the Homeric Greeks were consoled by the vision of Mount Olympus, even though they themselves never expected to enter its realm. And, since justice can only be realized in a community, there is a sense in which each of us who participates in that project shares a stake in its success, whether or not we ourselves will witness it. 
At this point, I return to the title of this paper, "Die Weltgeschichte ist das Weltgericht". It is most familiar as a phrase used by Hegel in Section 340 of the Philosophy of Right, but it is originally a line in a poem, Resignation: a Fantasy, by Friedrich Schiller, first published in 1786 (thus at the time that the "Pantheismusstreit" about Lessing and Spinoza was taking place in Germany).

Resignation depicts a soul who has come to the end of his life and now, as he believes, stands on the threshold of the Day of Judgement. In life, he has sacrificed himself for duty and kept faith with religion in the face of the scorn of the world. Now, surely, must come his reward. But as he makes his claim a voice replies to him: the world contains within it two flowers, pleasure (Genuss) and hope (Hoffnung). Those who choose to pluck the one must renounce the other. Hope is not just hope in pleasure in the future - if you choose hope, you must abstain. Thus the sentence "World history is the Last Judgement” denies the prospect of there being any reward for fidelity in a future life: hope must be its own reward.

Clearly the idea of "hope for hope's sake” is an unstable position, a kind of secular version of Pascal's wager. Once the corrosive forces of doubt enter into our belief in a future life, it seems inevitable that hope should be undermined. How can it be sustained, whatever its psychic and social benefits, if the object of our hope (a place of individual reward) is not credible? History, on the other hand, understood not as a judge that rewards and punishes individuals as they deserve, but as offering the prospect of progress towards a society of justice, does seem like a reasonable object of hope. 
It is important to explain how the idea of history as moving towards justice that I have been presenting contrasts with more familiar ways of connecting God and history. The eighteenth century was packed with accounts that presented history as a progressive unfolding of God's providence - that "temporalized", as Lovejoy put it, the "chain of being”, ${ }^{8}$ Yet, if, like Turgot, for example, we see history as being moved from a turbulent arena of violent passions to a calm scene of civilized interaction, how are we to understand it as an expression of divine benevolence and omnipotence? Perhaps a good outcome is produced in the end by all of this turmoil, but how can we judge as good a process in which, in Herder's words, "all preceding generations [were made] properly for the last alone, which is to be enthroned on the ruined scaffolding of the happiness of the rest." "Do you", asked Alexander Herzen, "truly wish to condemn the human beings alive today to the sad role of caryatids supporting a floor for others some day to dance on?” ${ }^{10}$ Is God not using past generations as a means for the end of the future?

Evidently, if God's goodness lies in the happiness of human existence, these objections are very forceful. Why should the consequential fact that existence at the end of the process is happy justify the unhappiness that is the means by which this happy end is reached? To this, there are two responses. First of all, from the Kantian point of view, the "inner principle" of the world is freedom, not happiness. And freedom, as Kant has argued so strenuously, is something that is available to all moral agents at all times. That which resists us and to which we need to be reconciled is not the absence of happiness but the lack of justice: the disproportion between happiness and desert. And this, as I have tried to show, is a reasonable object of hope, not just in another world but in this

\footnotetext{
${ }^{8}$ A.O. Lovejoy, The Great Chain of Being (Cambridge, MA: Harvard U.P., 1936), Ch. IX

${ }^{9}$ Reflections on the Philosophy of the History of Mankind, Bk VIII, Ch. 5

${ }^{10}$ Quoted in I. Berlin, Russian Thinkers (London: Penguin, 1994), p.105
} 
one. Certainly, though, Herder and Herzen's objections must be sustained on one level. If such a society were to be brought about, its justice would benefit those who were to live in it in the future, not those who must prepare the ground for it. But need this matter? If it is reasonable that the Greeks were consoled by the thought of the happy realm of Olympus (to which they would never have access) why should not modern human beings be consoled similarly by the thought of the just society of the future? While we may not live in the just society of the future, any more than the Greeks would live on Olympus, the fact that this ideal is embedded in our own history is not a matter of indifference to us.

The idea that modern human beings came to look to history for the realization of values that had previously been located in the redemptive promise of religion is, of course, by no means new. It is, after all, the subject of Carl Becker’s The Heavenly City of the Eighteenth-Century Philosophers, now more than seventy years old. Becker's famous work is problematic, however, both substantively and methodologically. He makes no distinction between those standard, Enlightenment views of history as a progress in human happiness from barbarism to civilization that were so typical of the mid-eighteenth century in France and Scotland in particular and the vision of history as pointing towards a future realization of justice that I have been concerned with here. Yet, in fact, as I have argued, the two are fundamentally different in their account of the moral status of history. The standard eighteenth-century Enlightenment accounts of historical progress, with their pictures of the beneficial effects of the development (and moderation) of human powers and passions, were certainly "Providentialist". History was represented as essentially the unfolding in time of the Deist view of the world as the expression of 
divine goodness. While there are elements of such a view in Kant (indeed, most writers on Kant fail to see that there is anything else) Kant's idea of history as oriented towards justice, not happiness, opens up, I have argued, a radical "post-Lisbon" answer to the problem of theodicy.

Still, although he provides no adequate conceptual analysis to support it, Becker’s last chapter does contain some very valuable material to document the independent appearance of a similar view of history in France at the end of the century. Becker quotes a very striking aphorism of Diderot's that "Posterity is for the philosopher what the other world is for the devout" ${ }^{\not 1}$ and follows it with a remarkable quotation from Condorcet. Condorcet, in his Esquisse pour un tableau historique des progrès de l'esprit humain (written, of course, while Condorcet was in hiding from the authorities) conjures up a vision of the future as a consolation for those who suffer injustice that perfectly illustrates what I have called the Apollonian image:

The contemplation of this picture is an asylum in which the memory of [the virtuous man's] persecutors does not follow him, an asylum in which, living in imagination with mankind re-established in its rights and in its true nature, he can forget mankind corrupted and tormented by greed, fear, envy. It is in this asylum that he truly lives with his fellows, in a heaven which his reason has created, and which his love of humanity embellishes with the purest joys. ${ }^{12}$

Other examples from the early years of the French Revolution give the idea of history as a divine judge a significantly different inflection. The debate in the Jacobin Club between Robespierre and Louvet and the memoirs of Madame Roland, written as she awaited the guillotine, were framed in terms of an appeal to the judgement of posterity. These are, says Becker, “essentially religious, essentially Christian” ideas. ${ }^{13} \mathrm{He}$

\footnotetext{
${ }^{11}$ The Heavenly City of the Eighteenth-Century Philosophers (New Haven, CT: Yale U.P., 1932), p.150

${ }^{12}$ The Heavenly City of the Eighteenth-Century Philosophers, p.151

${ }^{13}$ The Heavenly City of the Eighteenth-Century Philosophers, p.149
} 
thereby obscures what is, to my mind, the most significant point: that these "essentially religious” ideas were fundamentally transformed in being brought into a new context. The transfer of human hopes from heaven to history only becomes possible once it is no longer seen to be intolerable for individuals who have suffered not to have that suffering compensated by a direct experience of happiness in a future realm. What inspired the French neo-Roman republicans was not the traditional religious idea of a divine judge who would requite them for suffering in this world with bliss in another life. The reward they hoped for lay not in the sentence pronounced by the court of history being carried out and their pain compensated but in the verdict itself. Posterity would come to a just assessment of who was right, and the thought of being correctly understood and evaluated in the future was a source of present consolation, even though they would not experience their vindication.

For the German Idealists, it is not just that a future community will judge us justly; its connection to us in time makes us already a part of it. Our membership of such a community could reasonably be seen to connect us with the well-being of its other members even where we are not directly affected. As Kant puts it, the realization of justice requires a community: a "union of ... persons, a system of well-disposed human beings in which, and through the unity of which alone, the highest moral good can come to pass”. (Ak. 6:98) And what if that community were to be extended through time? In that case, a future society of justice would not be merely a remote, ideal vision, but part of the fulfilment of the destinies of those who have lived in the past.

Kant's radical successor, Fichte, makes exactly this move in his lectures “Concerning the Scholar's Vocation”. Our spirits are exalted, says Fichte, when we see 
the way in which human beings have co-operated in a community so that "the successful

progress of any member is the successful progress of them all” and all the more so, when

we think of it from our own perspective:

Our sense of our own dignity and power increases when we say to ourselves what every one of us can say: My existence is not in vain and without any purpose. I am a necessary link in that great chain which began at that moment when man first became fully conscious of his own existence and stretches into eternity. All these people have labored for my sake. All that were ever great, wise or noble those benefactors of the human race whose names I find recorded in world history, as well as the many more whose services have survived their names: I have reaped their harvest. Upon the earth on which they lived I tread in the footsteps of those who bring blessings upon all who follow them. Whenever I wish, I can assume that lofty task which they had set for themselves: the task of making our fellow men ever wiser and happier. Where they had to stop, I can build further. I can bring nearer to completion that noble temple that they had to leave unfinished."

"But,” someone may say, "I will have to stop too, just like they did.” Yes! And this is the loftiest thought of all: Once I assume this lofty task I will never complete it. Therefore, just as surely as it is my vocation to assume this task, I can never cease to act and thus I can never cease to be. That which is called "death" cannot interrupt my work; for my work must be completed, and it can never be completed in any amount of time. Consequently, my existence has no temporal limits: I am eternal. When I assumed this great task I laid hold of eternity at the same time. I lift my head boldly to the threatening stony heights, to the roaring cataract, and to the crashing clouds in their fire-red sea. "I am eternal!” I shout to them. "I defy your power! Rain everything down upon me! You earth, and you, heaven, mingle all of our elements in wild tumult. Foam and roar, and in savage combat pulverize the last dust mote of that body which I call my own. Along with its own unyielding project, my will shall hover boldly and indifferently over the wreckage of the universe. For I have seized my vocation and it is more permanent than you. It is eternal, and so too am I!"14

\footnotetext{
14 Fichte, “Some Lectures concerning the Scholar’s Vocation”, in Early Philosophical Writings, ed. D. Breazeale, (Ithaca, NY: Cornell U.P., 1988), pp. 144-184, 168-69
} 
Where Kant's ideal of justice led him towards both a future life and the idea of the establishment of a kingdom of God on earth, his immediate German Idealist successors developed a view of history that acts as a substitute for the redemptive hopes of traditional religious belief.

Michael Rosen

Department of Government, Harvard University mrosen@gov.harvard.edu 